University of Nebraska - Lincoln

DigitalCommons@University of Nebraska - Lincoln

Faculty Publications from the Harold W. Manter Laboratory of Parasitology

8-1972

\title{
Two Species of Acanthocephala from Australian Fishes with Description of Arhythmacanthus paraplagusiarum sp. $\mathrm{n}$.
}

\author{
Brent B. Nickol \\ University of Nebraska - Lincoln, bnickol1@unl.edu
}

Follow this and additional works at: https://digitalcommons.unl.edu/parasitologyfacpubs

Part of the Parasitology Commons

Nickol, Brent B., "Two Species of Acanthocephala from Australian Fishes with Description of Arhythmacanthus paraplagusiarum sp. n." (1972). Faculty Publications from the Harold W. Manter Laboratory of Parasitology. 360.

https://digitalcommons.unl.edu/parasitologyfacpubs/360

This Article is brought to you for free and open access by the Parasitology, Harold W. Manter Laboratory of at DigitalCommons@University of Nebraska - Lincoln. It has been accepted for inclusion in Faculty Publications from the Harold W. Manter Laboratory of Parasitology by an authorized administrator of DigitalCommons@University of Nebraska - Lincoln. 


\title{
TWO SPECIES OF ACANTHOCEPHALA FROM AUSTRALIAN FISHES WITH DESCRIPTION OF ARHYTHMACANTHUS PARAPLAGUSIARUM SP. N.
}

\author{
Brent B. Nickol \\ Department of Zoology, The University of Nebraska, Lincoln, Nebraska 68508
}

Abstract: Two South Australian garfish, Hemirhamphus melanochir, collected near Adelaide, South Australia, harbored 14 and 15 specimens of Micracanthorhynchina hemirhamphi. Arhythmacanthus paraplagusiarum sp. $\mathrm{n}$. is described from 10 specimens collected from Paraplagusia guttata taken from Moreton Bay, Brisbane, Queensland. A. paraplagusiarum differs from other species of the genus in length of the enlarged subapical proboscis hooks. These hooks are 120 to $132 \mu$ long in females and 113 to $120 \mu$ long in males of A. paraplagusiarum, 188 to $210 \mu$ long in A. fusiformis, and $60 \mu$ long in A. septacanthus. Males of A. paraplagusiarum have proboscides 182 to $206 \mu$ long compared to proboscides 340 to $430 \mu$ long in A. fusiformis.

Among unstudied helminths in the collection of Harold W. Manter were specimens of two acanthocephalan species collected near Brisbane, Queensland, and Adelaide, South Australia, in 1963 and 1964, respectively. All measurements are in microns with averages in parentheses unless otherwise stated. Description of Arhythmacanthus paraplagusiarum is based on six males and four females.

\section{Micracanthorhynchina hemirhamphi (Baylis, 1944) Ward, 1951}

Two South Australian garfish, Hemirhamphus melanochir, collected near Adelaide were parasitized by 29 specimens of Micracanthorhynchina hemirhamphi. One host harbored 14 of the acanthocephalans and the other 15. Specimens from this collection are within the range of variability previously reported for this species. M. hemirhamphi was described by Baylis (1944) from $H$. intermedius taken at Otage Harbor, New Zealand. It has been reported previously from the type host in South Australia (Johnston and Edmonds, 1952) and from Reporhamphus melanochir $(=H$. melanochir $)$ collected at Hobart, Tasmania (Edmonds, 1957).

\section{Arhythmacanthus paraplagusiarum sp. n.}

(Figs. 1-5)

\section{Description}

With characters of the genus. Trunk of both sexes short, fusiform; 2.5 to $3.3 \mathrm{~mm}$ long and 520 to 660 at widest point, middle third. Trunk spines,

Received for publication 23 March 1972.
10 to 12 long, evenly distributed from neck-trunk boundary posteriad about 425 . Proboscis globular; 202 to 221 (212) long, 168 to 187 (178) wide in females, 182 to 206 ( 196 ) long, 139 to 149 (145) wide in males; armed with 14 longitudinal rows of 5 or 6 hooks each. Proboscis hooks of 3 types; anterior hook in each longitudinal row thin, intermediate in length, not greatly recurved and with much reduced root or rootless; second hook in each row very long, not strongly recurved and with large prominent root; basal 3 or 4 hooks smallest and greatly recurved. Apical hooks of alternate rows, those reaching farthest anteriad, greatly reduced and rootless, 31 to 36 (35) long and 3 to 5 (4) thick proximally in both sexes. Apical hooks of other 7 rows moderately reduced, 60 to 72 (68) long and 7 to $10(8)$ thick at junction with small roots. Second hook in each row greatly enlarged, 120 to 132 (127) long and 17 thick at junction with root in females, 113 to 120 (116) long and 13 to 17 (15) thick in males. Roots of second hook in each row 60 to 65 (63) long in females, 50 to 53 (52) long in males. Basal 3 or 4 hooks of each row small, greatly recurved, and closely spaced; 22 to 26 (23) long anteriorly gradually decreasing to 12 to 17 (14) long posteriorly in both sexes. Neck 168 to 182 (179) long and 192 to 197 (196) wide in females, 158 to 168 (160) long and 154 to 182 (167) wide in males. Doublewalled proboscis receptacle attached at base of proboscis with ganglion near posterior end. Posterior walls of receptacle tip with large nuclei, 2 in outer wall and an undetermined number, ca. 5, in inner wall. Lemnisci unbranched, equal in length, 499 to 586 (528) long and 58 to $62(60)$ wide across tips, extending slightly beyond end of receptacle but not to level of anterior testis. Male reproductive system occupies 47 to $53 \%$ of trunk length. Contiguous, oval testes in tandem and similar in size, 336 to 422 (370) long and 202 to 269 (232) wide. Posterior testis in contact with anterior cement glands. Six club-shaped cement glands highly variable in size, 106 to 144 (125) 


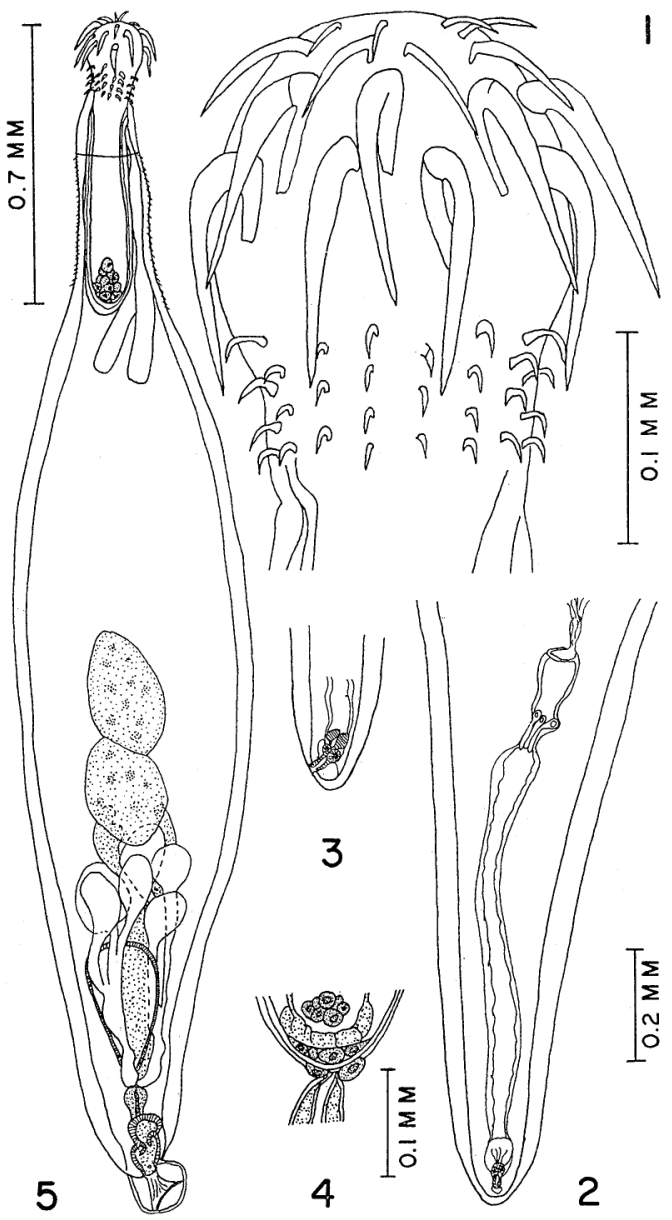

Frgures 1-5. Camera lucida drawings of Arhythmacanthus paraplagusiarum sp. n. Projection to right of Figure 2 applies equally to Figures 2-3. 1. Proboscis. 2-3. Posterior portions of females. 2. Ventral view. 3. Lateral view. 4. Posterior tip of proboscis receptacle. 5. Male, entire.

at widest points; arranged in 2 groups of 3 glands each. Ducts from glands of each pair join forming a reservoir on each side of Saefftigen's pouch. Female reproductive system occupies about 33\% of trunk length; uterine bell (visible in only 1 specimen) 215 long, inclusive of selector apparatus, and 65 wide; neck of selector apparatus 15 wide. Uterus about 800 long and 70 wide. Eggs with fully formed shells not observed.

Type host: Paraplagusia guttata.

Type locality: Moreton Bay, Brisbane, Queensland, Australia.

Type specimens: USNM Helm. Coll. holotype male No. 72253, allotype female No. 72254, paratype No. 72255. Additional paratypes, Division of Parasitology, Nebraska State Museum Nos. 20001 and 20002, and in collection of author.

\section{Remarks}

Female specimens with fully formed eggs were not observed. However, since all females studied possessed eggs nearly in full development measurements probably are very close to those that would have resulted from study of older specimens.

Quincuncially arranged hooks on the anterior portion of the proboscis of specimens of Arhythmacanthus have often been described as spiral rows. It seems more convenient, however, to describe them as staggered longitudinal rows since proximally they match longitudinal rows of spines (Fig. 1).

The cluster of large nuclei associated with the posterior extremity of the proboscis receptacle of Arhythmacanthus paraplagusiarum is suggestive of those possessed by species of Fessisentis (Fig. 4). In A. paraplagusiarum the nuclei seem more variable in size and number and are less apparent than are those of Fessisentis species. It is not known if other species of Arhythmacanthus possess similar nuclei associated with the receptacle. Further study of receptacle sac structure, a feature of considerable taxonomic importance, is needed for species of both genera.

Arhythmacanthus paraplagusiarum differs from all other species of the genus in length of enlarged subapical hooks. Yamaguti (1935) described those hooks as 188 to 210 long in A. fusiformis and Golvan (1969) reported the longest hooks of A. septacanthus as 60 long. The largest proboscis hooks of A. paraplagusiarum are, therefore, much shorter than those of $A$. fusiformis and much longer than those of A. septacanthus. Males of $A$. paraplagusiarum have proboscides 182 to 206 long compared to 340 to 430 in A. fusiformis.

In 1949, Arhythmacanthus septacanthus was first described in a thesis at the University of India by Sita. Since this does not meet criteria for publication, Golvan (1969) repeated the description and name in a manner which validated it, but gave the author and date citation as Sita, 1949. Since Sita is clearly responsible for the name, he is correctly cited as its author, but the date of availability is 1969 (Int. Code Zool. Nom., Arts. 50 and 10, respectively) and the complete name, author, and date citation is 
Arhythmacanthus septacanthus Sita in Golvan, 1969.

\section{LITERATURE CITED}

BAyLis, H. A. 1944. Three new Acanthocephala from marine fishes of Australasia. Ann. Mag. Nat. Hist., Ser. 11, 11 : $462-472$.

Edmonds, S. J. 1957. Acanthocephala. Brit., Austral., N. Zeal. Antarctic Res. Exped. 19211931. Rep. Ser. B 6: 93-98.

Golvan, Y. J. 1969. Systématique des Acanthocéphales (Acanthocephala Rudolphi, 1801), l'ordre des Palaeacanthocephala Meyer, 1931, la superfamille des Echinorhynchoidea (Cobbold, 1876) Golvan et Houin, 1963. Mem. Mus. Nat. Hist. Nat. Nouvelle serie A, Zool. 4.2: 1-373.

Johnston, T. H., ANd S. J. Edmonds. 1952. Australian Acanthocephala No. 9. Tr. Roy. Soc. S. Austral. 75: 16-21.

YAMAGUTI, S. 1935. Studies on the helminth fauna of Japan. Part 8. Acanthocephala, I. Jap. J. Zool. 6: 247-278. 